\title{
nature
}

\section{1 uses for a dead bird}

Natural history museums face an unprecedented opportunity as central players in biodiversity research. They and their financial supporters need to match fine words with appropriate actions.

$\mathrm{P}$ resident Thomas Jefferson had a better appreciation of the importance of biodiversity research than many contemporary politicians. When the United States acquired Louisiana Territory from France in the early nineteenth century, he sent scientists to record its climate, biota, minerals and peoples, as well as "the dates at which particular plants put forth or lose their flowers or leaf, times of appearance of particular birds, reptiles or insects". Jefferson's mandate vividly illustrates that natural history collections are much more than aesthetic displays of stuffed birds or dried plants; they are databases compiling taxonomic, systematic and ecological information on species and their habitats.

An invaluable heritage of some 3 billion specimens has accumulated in museums worldwide as a result of expeditions carried out over the centuries. Museum directors, keen to capitalize on contemporary political enthusiasm for biodiversity, are now rightly asserting that their natural history collections are essential to underpin efforts to create the detailed picture of the Earth's biota that will provide a baseline for its responsible management (see page 115). That much has been acknowledged by the signatories to the United Nations Biodiversity Convention, while a strong case for much greater support for museum research is contained in a recent report by the US President's Committee of Advisors on Science and Technology (PCAST).

Fine words from politicians in the United States and elsewhere have yet to be matched by significant increases in funding. But imagine the mess were genome databases of maps and sequences isolated in regional repositories instead of being available to the world's biology community at the click of a Web page. Imagine also that the data had few if any links to related information and lacked reliable quality control, with much being redundant, incomplete or duplicated.

That is the situation that currently reigns in the management and exploitation of many of the world's natural history collections. The most pressing need is for a physical refurbishment to preserve existing collections, along with an international digitization programme to create a seamless web linking taxonomic and systematic information from the world's collections with ecological and biogeographical databases - such as that being proposed by the Megascience Forum of the Organization for Economic Cooperation and Development.

That basic infrastructure is needed if new data are to be efficiently incorporated from efforts to create an inventory of the millions of species that have yet to be described, such as the proposed Systematics Agenda 2000 programme. It is also required in order to put all biodiver- sity research on a firmer scientific footing. In one sense, biodiversity research is what museums should have been doing for centuries, and their relative unpreparedness suggests that they have fallen short in their role as custodians of the Earth's biodiversity. But museums have often had barely enough funds to keep collections from deteriorating, let alone to begin to think of making them more sophisticated or embarking on vast new inventory efforts.

Nevertheless, museum directors everywhere need to scrutinize their consciences to ensure that they are defending their core missions with sufficient zeal, and not neglecting them through an excessive pursuit of the short-term political favour and revenues that can flow from their public exhibitions. It is also a paradox that whereas biodiversity research is eminently global, museums have often been parochial in outlook and have tended to focus on their own collections. It is increasingly clear that museums can no longer afford to work in isolation.

That message seems to be hitting home. Europe's major museums have formed a consortium, while the PCAST report calls for a coordinated interdisciplinary approach to biodiversity incorporating museums and the disparate federal agencies involved. An embryo of a credible umbrella organization for biodiversity science is also emerging in the form of Diversitas, a body under the auspices of UNESCO and the International Council for Scientific Unions.

One priority should be increased scientific collaboration between museums in the diversity-poor but economically rich nations and the diversity-rich but economically poor countries. Not only are developing countries home to most of the world's biodiversity, but the relatively low costs of such research puts excellence within their means. Mexico's National Commission for the Knowledge and Use of Biodiversity provides a shining example of what can be achieved - with an annual budget of just $\$ 2.5$ million, it has sent scientists to museums worldwide to digitize existing specimens of Mexico's biota. By integrating the resulting data with ecological and other databases, it has built what many Western scientists acknowledge is one of the most powerful biodiversity management systems around.

The urgent need now is for museums and other bodies involved in biodiversity research to organize and reach international scientific consensus on priorities for funding. Efforts by Diversitas and other groups to identify gaps where knowledge is lacking about particularly ecologically important or endangered groups are a good start, as is the PCAST report's agenda. That process of prioritization needs to be accelerated and deepened.

\section{New policy for structure data}

ike other leading journals, Nature has in recent months been considering a change in editorial policy, requiring that high-resolution structural coordinate data be made freely available at the time of publication, rather than allowing the option of a one-year hold on such release (see Nature 391,$617 ; 1998$ ). It is clear that there is a significant majority opinion in the community against permitting a one-year hold. Accordingly, Nature, simultaneously with Science, is changing its policy. Any paper containing new structural data received on or after 1 October 1998 will not be accepted without an accession number from the Brookhaven Protein Data Bank (PDB) accompanied by an assurance that unrestricted ("layer-1") release will occur at or before the time of publication (see April 1998 PDB Newsletter at www.pdb.bnl.gov/pdb-docs/newsletter.html). We will undertake to notify the PDB ahead of publication to ensure that the data are unlocked on the appropriate date.

Philip Campbell Editor, Nature 